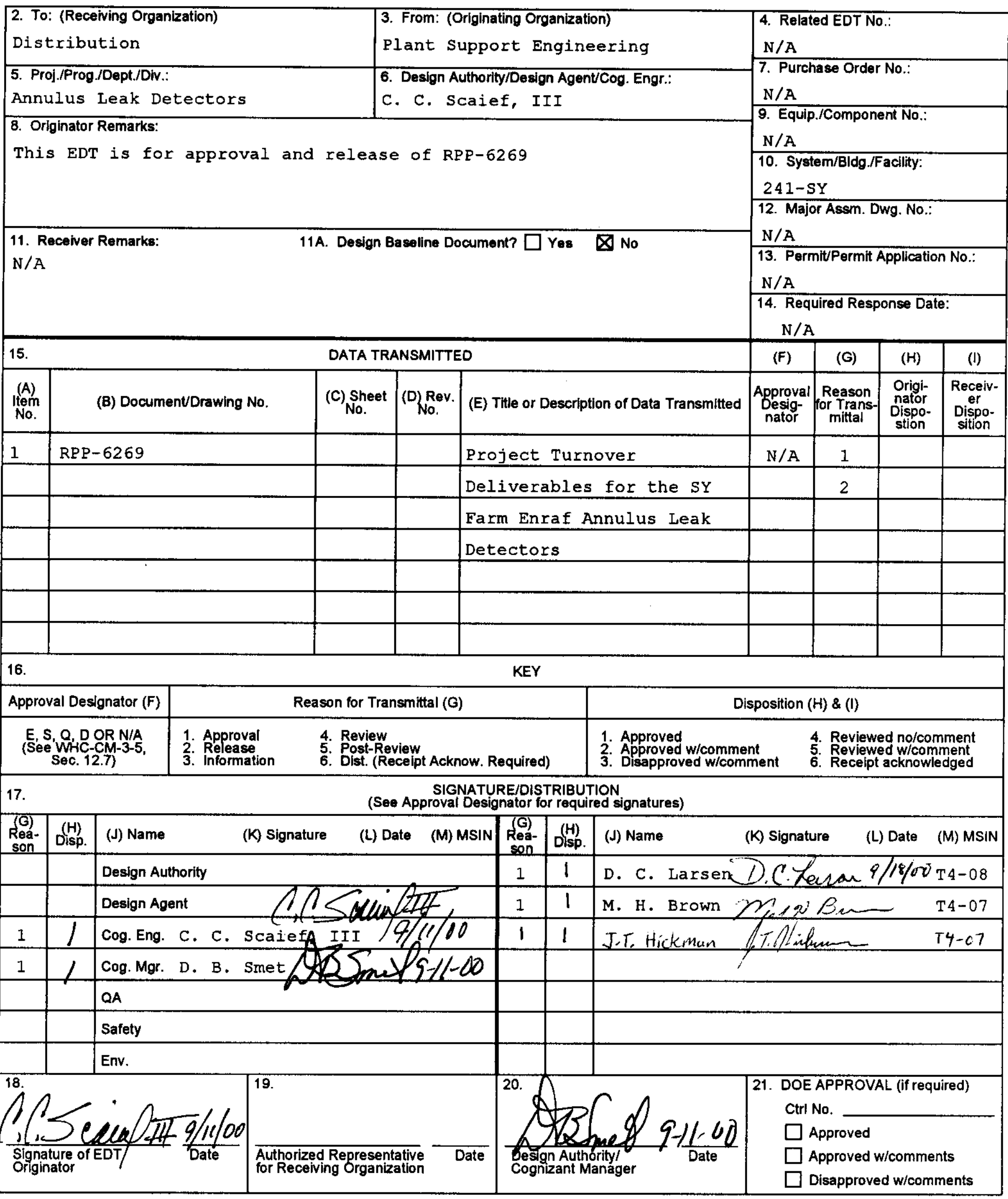




\section{DISTRIBUTION SHEET}

To

Distribution

Project TitleMork Order

Project Turnover Deliverables for the SY Farm Enraf Annulus Leak Detectors, RPP-6269

\begin{tabular}{l}
\hline \\
\hline M. H. Brown \\
\hline K. E. Carpenter \\
\hline D. C. Larsen \\
\hline C. C. Scaief III \\
\hline J. T Hickman \\
\hline
\end{tabular}

From

Plant Support Engineering Name

$$
\text { J.T Hickman }
$$

\begin{tabular}{|c|c|c|c|c|}
\hline MSIN & $\begin{array}{c}\text { Text } \\
\text { With All } \\
\text { Attach. }\end{array}$ & Text Only & $\begin{array}{c}\text { Attach./ } \\
\text { Appendix } \\
\text { Only }\end{array}$ & $\begin{array}{c}\text { EDT/ECN } \\
\text { Only }\end{array}$ \\
\hline T4-07 & $x$ & & & \\
\hline R3-47 & $x$ & & & \\
\hline T4-08 & $x$ & & & \\
\hline R3-83 & $x$ & & & \\
\hline$T 4-07$ & $x$ & & & \\
\hline
\end{tabular}

\begin{tabular}{|l|l|} 
Page 1 of 1 \\
Date $09 / 11 / 00$ \\
\hline
\end{tabular}

EDT No. 629685

ECN No. N/A

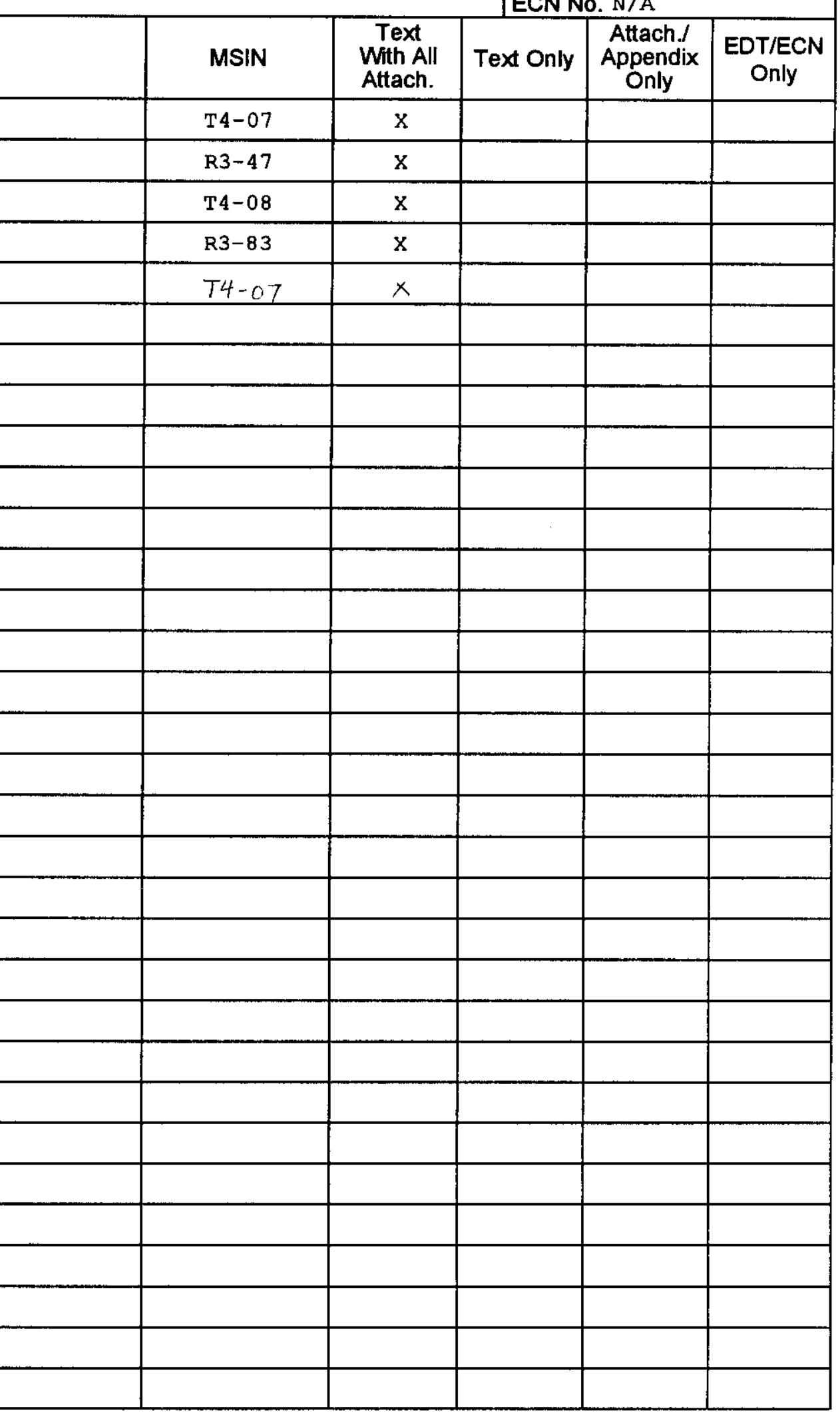




\title{
Project Turnover Deliverables for the SY Farm Enraf Annulus Leak Detectors
}

\author{
C. C. Scaief, III \\ CH2M HILL Hanford Group, Inc. \\ Richland, WA 99352 \\ U.S. Department of Energy Contract DE-AC06-99RL14047 \\ EDT/ECN: 629685 \\ Cost Center: 7M100 \\ UC: $512 \& 2030$ \\ B\&R Code: EW3120071 \\ Charge Code: 109830 \\ Total Pages: 8
}

Key Words: Annulus, leak detector

Abstract: This document identifies the deliverables that ensure the end user of the SY Farm Enraf Annulus Leak Detectors (ALD) has all the documentation and training required for operating and maintaining the new system.

TRADEMARK DISCLAIMER. Reference herein to any specific commercial product, process, or service by trade name. trademark, manufacturer, or otherwise, does not necessarily constitute or imply its endorsement, recommendation, or favoring by the United States Government or any agency thereof or its contractors or subcontractors.

Printed in the United States of Amerlca. To obtain copies of this document, contact: Document Control Services, P.O. Box 950, Mailstop H6-08, Richland WA 99352, Phone (509) 372-2420; Fax (509) 376-4989.
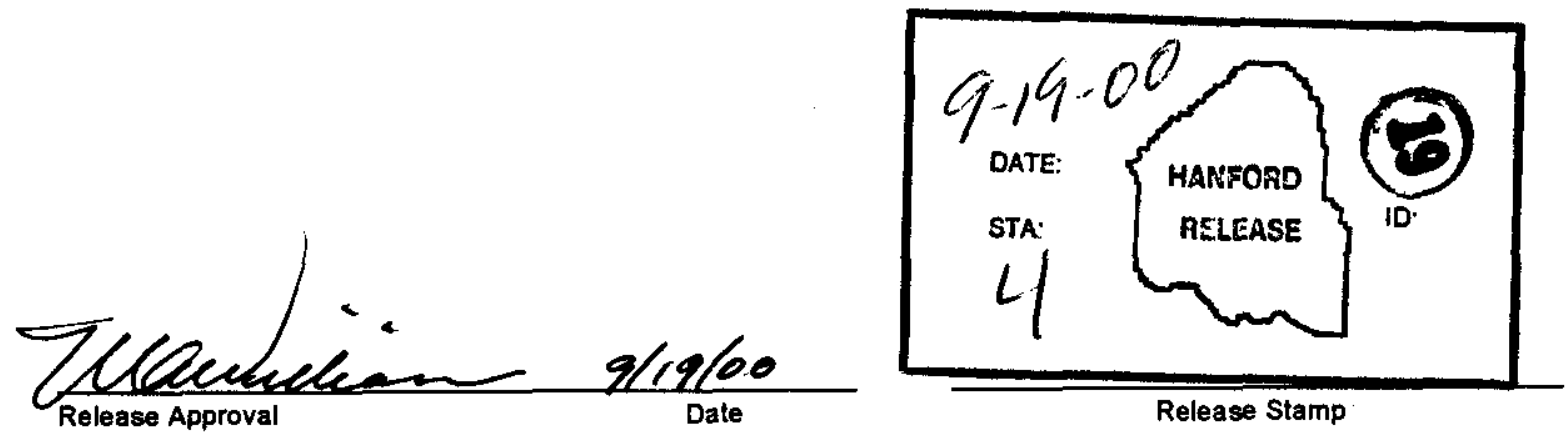

Approved For Public Release 


\section{PROJECT TURNOVER DELIVERABLES FOR THE SY FARM ENRAF ANNULUS LEAK DETECTORS}

C. C. Scaief, III 


\section{PROJECT TURNOVER DELIVERABLES FOR THE SY FARM ENRAF ANNULUS LEAK DETECTORS}

\section{TABLE OF CONTENTS}

\subsection{INTRODUCTION}

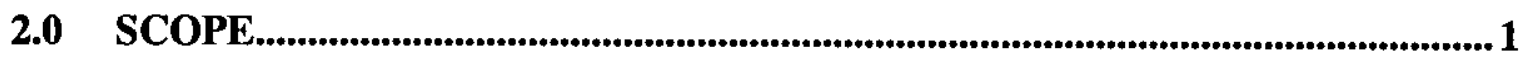

3.0 DELIVERABLES ............................................................................................................. 1

4.0 REFERENCES ............................................................................................................... 4

5.0 APPENDIX A: ACCEPTANCE FOR BENEFICIAL USE FORM.....................5 


\section{PROJECT TURNOVER DELIVERABLES FOR THE SY FARM ENRAF ANNULUS LEAK DETECTORS}

\subsection{INTRODUCTION}

This document identifies the deliverables that ensure the end user of the SY Farm Enraf Annulus Leak Detectors (ALD) has all the documentation and training required for operating and maintaining the new system. All deliverable items checked on the Acceptance For Beneficial Use (ABU) form have been completed and are available to the end user. This document was written as required by HNF-IP-0842, Volume IV section 3.12 Acceptance of Structures, Systems, and Components for Beneficial Use.

\subsection{SCOPE}

This document applies to the deliverable documentation required to operate and maintain the SY Farm Enraf ALD System. Appendix A provides a copy of the ABU form as listed in the appendix of TWR-4092, Engineering Task Plan for the New SY Farm Annulus Leak Detectors. This document attests that all required deliverable items checked on the ABU have been completed and are available to the end user.

\subsection{DELIVERABLES}

The following are the deliverable items on the ABU form with the document title.

\section{Engineering Task Plan}

TWR-4092, Engineering Task Plan For the New SY Farm Annulus Leak Detectors

\section{Drawings}

H-14-103761, Sheet 1-3, Rev.0 Installation Annulus Leak Detector Electrical

\section{SY Farm ECNs}

ECN-655929 SY Annulus LDT (modifies H-14-103761, sheets 1 and 3)

ECN-655940 Annulus Leak Detectors (modifies H-14-103761, sheet 1, 2 and 3)

ECN-647464 Annulus Leak Detectors (Installs SY-102, Riser -033 ALD)

ECN-647475 Annulus Leak Detectors (Changes ECN-647464)

ECN-647466 Annulus Leak Detectors (Changes ECN-647464) 
ECN-647470 Annulus Leak Detectors (As-Builds H-2-72378, Sheet 1, Rev. 0)

ECN-649073 Enraf Annulus Leak Detector (Adds ALD displacer to H-2-817634)

ECN-647473 Annulus Leak Detectors (Installs riser adapters and ball valves on the eight remaining risers)

ECN-655930 Annulus Leak Detectors (Changes ECN-647473)

ECN-647472 Annulus Leak Detectors (Installs conduit for the nine ALD risers)

ECN-651866 Annulus Leak Detectors (Supersedes ECN-647472)

ECN-647474 Installs the eight ALDs on the risers and connects them to TMACS and the alarm circuits.

ECN-655948 Annulus Leak Detectors (Changes ECN 647474)

ECN-655946 Annulus Leak Detectors (Adds auxilliary ground connection for portable generator)

ECN-655931 Reconfigures the alarm circuit and modifies the SEL

Authorization Basis

LMHC 2000a, Tank Waste Remediation System Final Safety Analysis Report, HNFSD-WM-SAR-067, Rev. 1-G, Lockheed Martin Hanford Corporation, Richland, Washington

LMHC 2000b, Tank Waste Remediation System Technical Safety Requirements, HNFSD-WM-TSR-006, Rev. 1-G, Lockheed Martin Hanford Corporation, Richland, Washington

\section{SY Farm Procedures}

TO-040-590, LEAK DETECTION WELLS ANULUS LEAK DETECTION SYSTEMS

ARP-T-431-101, RESPOND TO ALARMS IN THE 241-SY-271 INSTRUMENT BUILDING

TF-OR-WST-01-D, 242-S, 244-S, 241-S AND 241-SX DAY AND NIGHT SHIFT ROUNDS

TF-FT-439-009, PERFORM FUNCTIONAL TEST OF 241-SY PRIMARY TANK 
LEAK DETECTION SYSTEM ANNULUS ENRAF LEAK DETECTORS

6-LDD-485, CALIBRATE PRIMARY TANK ENRAF (SERIES 854) LEAK

DETECTION GAUGES LOCATED IN ANNULUS TANKS AND CHECK

DISPLACER WEIGHT

5-LDD-468, ANNULUS TANK LEAK DETECTION ENRAF SERIES 854 INITIAL INSTALLATION AND OPERATIONAL CHECK

\section{SY Farm Data Sheets}

Activity \# Component Number

WT-06636 241-SY-ANN-LDT

WT-06522 SY101-WSTA-LDT-151

WT-06523 SY101-WSTA-LDT-152

WT-06524 SY101-WSTA-LDT-153

WT-06525 SY102-WSTA-LDT-151

WT-06526 SY102-WSTA-LDT-152

WT-06527 SY102-WSTA-LDT-153

WT-06528 SY103-WSTA-LDT-151

WT-06529 SY103-WSTA-LDT-152

WT-06530 SY103-WSTA-LDT-153

Acceptance Test Procedure (ATP) and Test Report $\underline{\text { (ATR) }}$

HNF-4634, Rev. 0, Test Plan for SY Farm Annulus Leak Detector

HNF-4328, Rev. 0, Test Report for ENRAF Annulus Leak Detector Development

\section{Procedure}

TF-FT-439-009

6-LDD-485

6-LDD-485

6-LDD-485

6-LDD-485

6-LDD-485

6-LDD-485

6-LDD-485

6-LDD-485

6-LDD-485

\section{Description}

Overall test plan

Proof of concept test and report 
RPP-6269

Revision 0

HNF-4546, Rev. 1, ENRAF Series 854 Advanced Technology Gauge (ATG) with SPU II Card for Leak

Detector Use Acceptance Test

HNF-5155, Rev 0, Acceptance Test Report for the SY102 Annulus Leak Detector Demonstration Unit

HNF-5397 Test Report for New SY Farm Annulus Leak Detectors, Rev.0

HNF-5467 In Shop Acceptance Test Report for the SY Farm Annulus Leak Detectors, Rev. 0
Shop Acceptance Test Procedure

Report for HNF-4546 (shop ATP) for SY-102 gauge

Test report for SY-102 demonstration period

Report for HNF-4546 (Shop ATP) for the remaining eight gauges

\section{Vendor Information Files}

31560 (Existing Enraf VI File)

\section{Training Completed}

Training Bulletin RPP-TB-99-18 - Enraf Annulus Leak Detector (ALD) in SY Tank Farms.

\subsection{REFERENCES}

TWR-4092, Engineering Task Plan For New SY Farm Annulus Leak Detectors

HNF-IP-0842, Volume IV section 3.12, Acceptance of Structures, Systems, and Components For Beneficial Use. 
5.0 APPENDIX A: ACCEPTANCE FOR BENEFICIAL USE FORM DOCUMENTATION REQUIRED FOR ACCEPTANCE FOR BENEFICIAL USE

\begin{tabular}{|c|c|c|c|}
\hline DESCRIPTION & RESPONSIBILITY & DESCRIPTION & RESPONSIBILITY \\
\hline 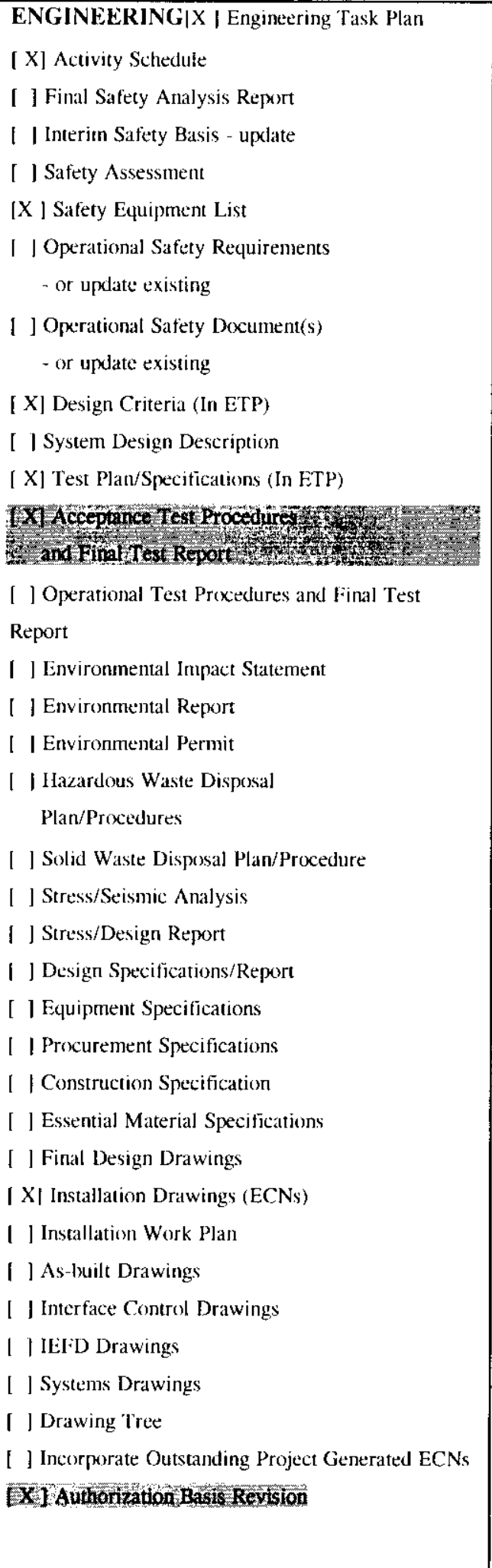 & $\begin{array}{l}\text { CC Scaief IlI } \\
\text { JH Huber } \\
\text { JH Huber }\end{array}$ & 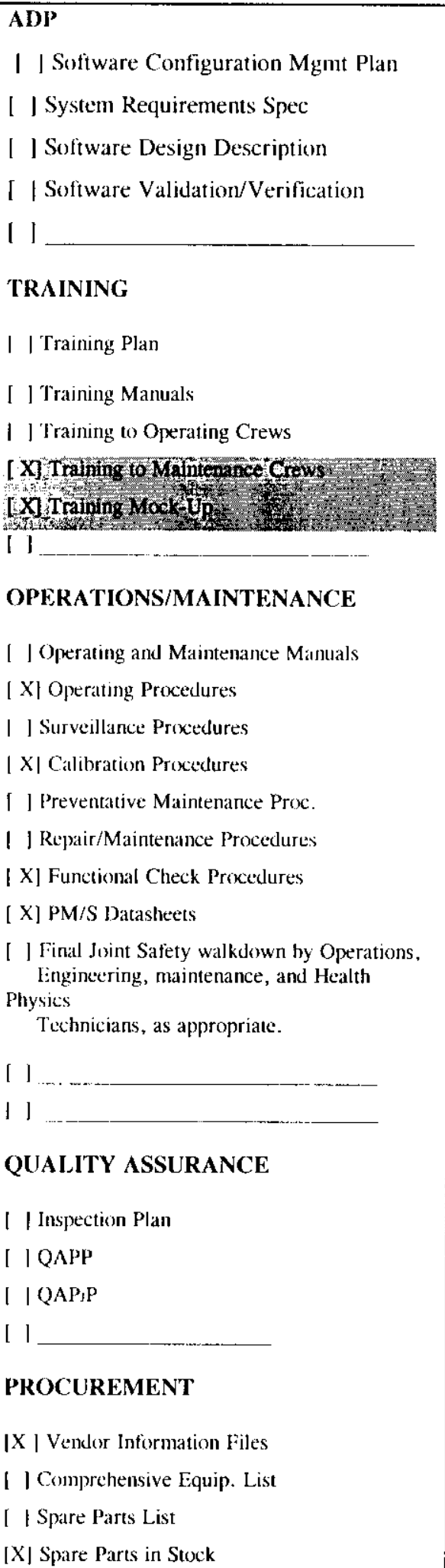 & $\begin{array}{l}\text { DC Larsen } \\
\text { DB Smet } \\
\text { DB Smet } \\
\text { DB Smet }\end{array}$ \\
\hline
\end{tabular}

